\title{
LEAD AND NEODYMIUM ISOTOPIC RESULTS FROM METABASALTS OF THE HAVERI FORMATION, SOUTHERN FINLAND: EVIDENCE FOR PALAEOPROTEROZOIC ENRICHED MANTLE
}

\author{
MATTI VAASJOKI and HANNU HUHMA
}

\begin{abstract}
VAASJOKI, MATTI and HUHMA, HANNU 1999. Lead and neodymium isotopic results from metabasalts of the Haveri Formation, southern Finland: evidence for Palaeoproterozoic enriched mantle. Bulletin of the Geological Society of Finland 71, Part 1, 143-153.

Tholeiitic metabasalts and coexisting sulphides have been analysed for their $\mathrm{Pb}$ and $\mathrm{Nd}$ isotopic compositions from the Proterozoic Haveri Formation, which forms the basal unit of the Tampere Schist Belt in southern Finland. Ten whole rock samples analysed for $\mathrm{Pb}$ isotopes form a sublinear array which yields rather uncertain age estimates in the $1900-2000 \mathrm{Ma}$ range and lies on the ${ }^{207} \mathrm{~Pb} /{ }^{204} \mathrm{~Pb}$ vs. ${ }^{206} \mathrm{~Pb} /{ }^{204} \mathrm{~Pb}$ diagram well below the average global lead evolution curve. The initial lead isotopic composition inferred from the whole rock data and measured on chalcopyrite is the least radiogenic obtained from the Svecofennian domain, and precludes involvement of old upper crustal material in basalt genesis. This together with the geochemical composition and initial $\varepsilon_{\mathrm{Nd}}(1900)$ of $+0.5 \pm 0.6$ suggest that the Haveri mafic metavolcanic rocks were not derived from convective MORB-type mantle. The source was rather a mantle, which had been enriched in LREE for a considerable time period.

Some chalcopyrite trace leads plot close to the whole rock array while others lie above it. This is interpreted as indicating two distinct mineralisation processes. The primary and major process involved lead which was cogenetic with the basalts, while the second mineralising fluid introduced radiogenic (high ${ }^{207} \mathrm{~Pb}$ ) upper crustal lead scavenged from the adjacent sedimentary rocks.

The least radiogenic leads at Haveri and in the Outokumpu ophiolite complex some $300 \mathrm{~km} \mathrm{NE}$ are similar and the two occurrences can be coeval. The preservation of original mantle material at Haveri may be interpreted as suggesting that continental crust had formed in the Tampere area 1900-2000 Ma ago.
\end{abstract}

Key words: metavolcanic rocks, metabasalt, sulfides, absolute age, $\mathrm{Pb} / \mathrm{Pb}, \mathrm{Sm} /$ Nd, genesis, Paleoproterozoic, Haveri, Finland

Matti Vaasjoki and Hannu Huhma: Geological Survey of Finland, Box 96, FIN02151 Espoo, Finland

E-mail: matti.vaasjoki@gsf.fi 

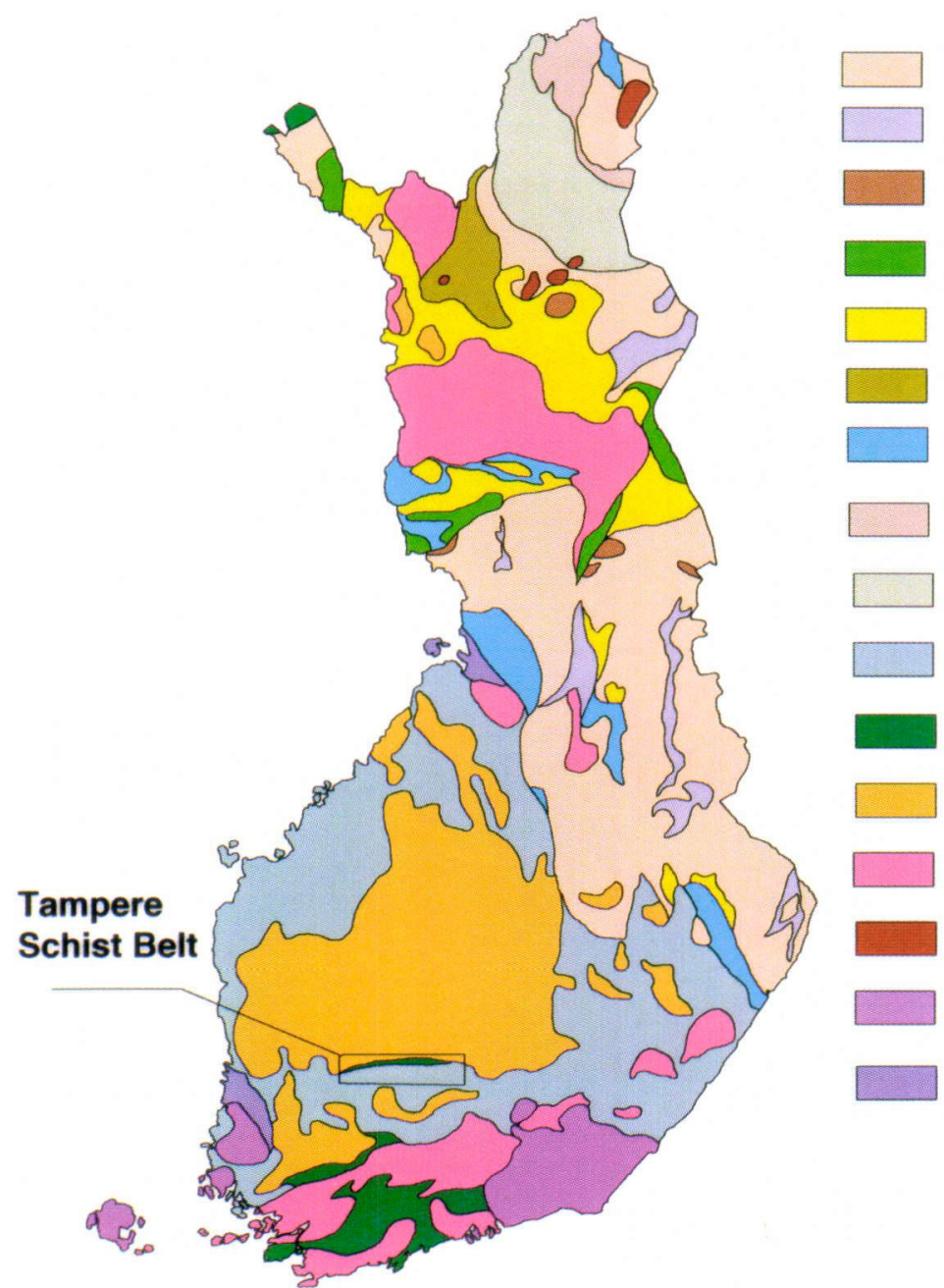

Archaean granitoids and gneisses

Archaean greenstone belts

Layered gabbro intrusions

Metavolcanic rocks

Quartzites and schists

Central Lapland greenstone belt

Cratonic mica schist

Inari gneisses and gabbros

Lapland granulite belt

Mica schists and migmatites

Metavolcanic rocks

Synorogenic granitoids

Late orogenic granites

Postorogenic granitoids

Rapakivi granites

Sandstones and shales

$200 \mathrm{~km}$

Fig. 1. Location of the Tampere Schist Belt in Finland. Simplified from Simonen (1980a).

\section{INTRODUCTION}

The Tampere Schist Belt (Figs. 1 and 2) has been regarded as one of the key areas of the Finnish Precambrian since the times of Sederholm (1897) and has been subject to almost continuous geological study ever since (Neuvonen \& Matisto 1948, Seitsaari 1951, Simonen \& Kouvo 1951, Simonen 1952, 1953, Campbell 1980, Gaál et al. 1981, Kähkönen 1989, Kähkönen \& Leveinen 1994). This belt, more than $200 \mathrm{~km}$ long in an E-W direction, reaches locally maximum widths of about $20 \mathrm{~km}$ and comprises metasedimentary and meta- volcanic rocks intruded by a variety of granitoids. The metasedimentary rocks were originally mainly greywackes and pelites, with minor conglomerates, arkoses and black shales. Calcareous rocks are rare and quartzites are virtually absent. The metavolcanic rocks are generally pyroclastic in origin but contain also subordinate lavas and subvolcanic rocks. Their composition ranges from basaltic to rhyolitic, with intermediate types occurring most frequently. The basement of deposition for the belt has so far remained obscure. The regional metamorphism has commonly peaked under low-pressure amphibolite facies conditions, 


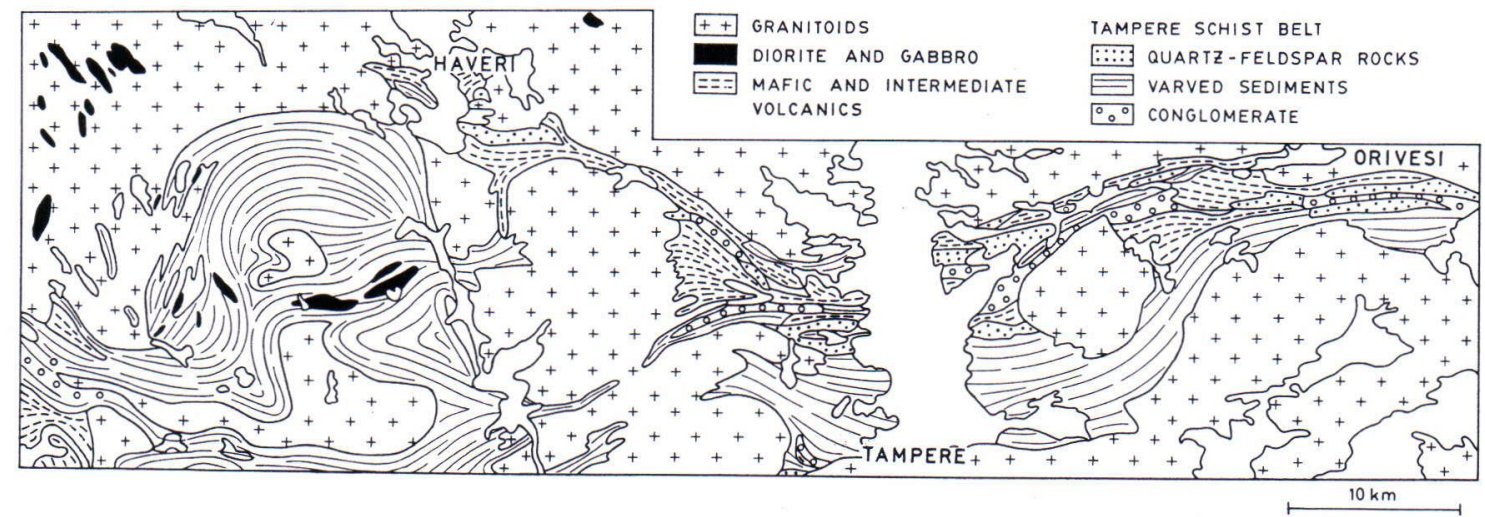

Fig. 2. Generalized geological map of the Tampere Schist Belt and its surroundings. After Simonen (1980b) and Kähkönen (1989).

which has resulted in the preservation of a number of primary sedimentary and volcanic textures.

Previous geochronologic and isotopic studies of the area indicate that the igneous rocks register ages normal in the Svecofennian environment. A stratigraphically low metavolcanic rock has a zircon age of 1904 \pm 4 Ma (Kähkönen et al. 1989), while the upper volcanic sequence has been dated at $1889 \pm 5 \mathrm{Ma}$ (op. cit.). Both volcanic sequences and the sedimentary pile inbetween were deformed by granitoid intrusions dated at $1880 \mathrm{Ma}$ (Kähkönen et al. 1989, Nironen 1989) by U-Pb on zircons. From one of these, the Hämeenkyrö Batholith, $\mathrm{Rb}-\mathrm{Sr}$ whole rock analyses have yielded an age of $1775 \pm 52 \mathrm{Ma}$ and the initial ${ }^{87} \mathrm{Sr} /{ }^{86} \mathrm{Sr}$ ratio is, at 0.703 , suggestive of a slightly evolved Palaeoproterozoic source. A similar indication is given by the $\varepsilon_{\mathrm{Nd}}$ value of +0.1 (Patchett \& Kouvo 1986).

The provenance of the metasedimentary rocks in the Tampere Schist Belt has been of some concern as original data on detrital zircons indicated ages of ca. $2300 \mathrm{Ma}$ (Kouvo \& Tilton 1966), and $\mathrm{Nd}$ isotopic studies (Huhma 1987) yielded $\mathrm{T}_{\mathrm{DM}}$ model ages of similar order. However, ionprobe work has established that these data reflect a mixing of two sources, a minor late Archaean one and a dominating Palaeoproterozoic one dated to be 1.9-2.1 Ga old (Huhma et al. 1991, Claesson et al. 1993). Considering the error limits, the youngest detrital zircon grain gives a maximum estimate of $1950 \mathrm{Ma}$, and thus the deposition of the metasediments in the Tampere Schist Belt must have occurred between 1950 and $1880 \mathrm{Ma}$.

This study aimed primarily to test whether the Au-bearing sulphide mineralisation is genetically linked with the tholeiitic metabasalts and to determine the initial lead and neodymium properties of the system. A proven genetic link between the sulphide mineralisation and the metabasalts would influence the planning of exploration for auriferous mineral deposits within the Tampere Schist Belt and an insight into the origin of the oldest rocks occurring in the Tampere Schist Belt could have a profound influence on the understanding of the Palaeoproterozoic evolution of the Fennoscandian Shield.

\section{THE HAVERI FORMATION AND THE SULPHIDE ORES}

The rocks around the Haveri mine (Fig. 3) are mainly tholeiitic basalts metamorphosed in medium grade conditions $\left(\mathrm{P}=2.5 \mathrm{kbar}, \mathrm{T}=550^{\circ} \mathrm{C}\right.$; Mäkelä 1980) and are cut by granodiorite stocks, a metadacite dyke and biotite-amphibolite dykes. The intermittent pillow structures in the metabasalts constitute strong evidence for a seafloor origin of these rocks. The folded mafic metavolcanic and associated rocks in the immediate vicinity of the mine form a distinct lithological unit with an 


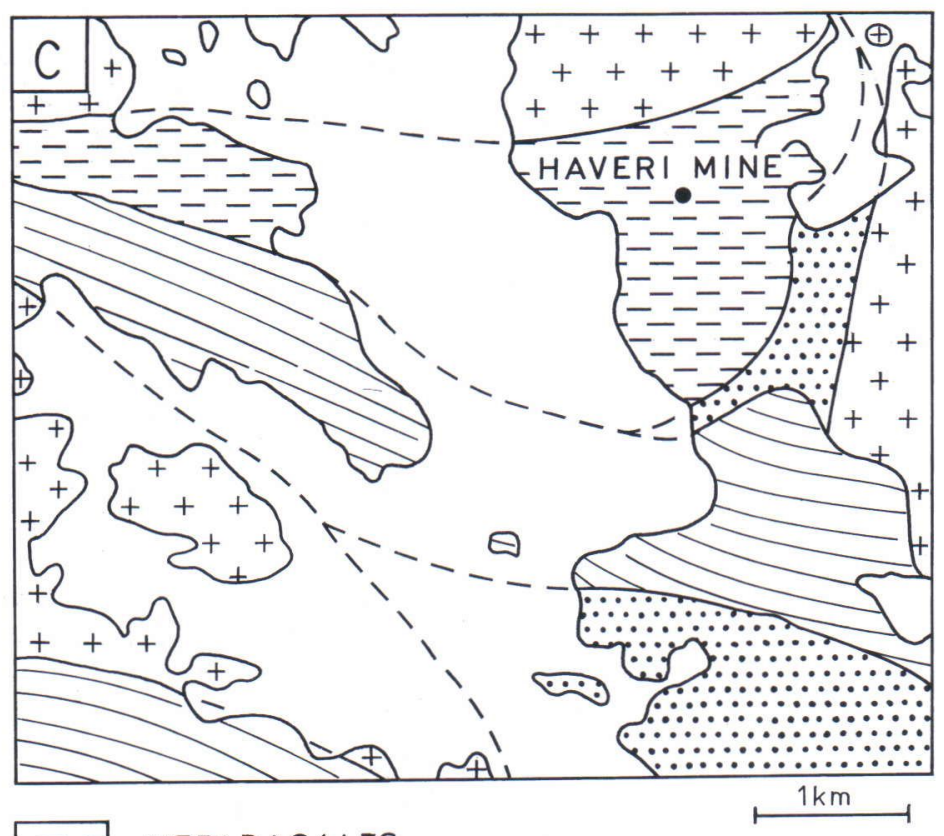

--7 METABASALTS
Fig. 3. Geology of the Haveri area. After Mäkelä (1980).

\section{$::::$ ACIDIC TO INTERMEDIATE METAVOLCANICS}

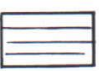

$++^{+}$

\section{METAGREYWACKES}

\section{GRANITOIDS}

area of about $10 \mathrm{~km}^{2}$. Simonen (1953) includes the mafic metavolcanic rocks in the uppermost stratigraphic unit of the Tampere Schist Belt. Although this concept appears to be generally correct, the Haveri Formation is now considered to be the oldest supracrustal unit in the Tampere Schist Belt (Mäkelä 1980, Kähkönen \& Nironen 1994), and has been shown to grade into the metaturbidites of the overlying Osara Formation on the western shore of Kyrösjärvi.

The sulphide ores consist mainly of pyrrhotite, with subordinate chalcopyrite and magnetite as well as accessory fahlores, sphalerite, molybdenite and ilmenite. They occur most often within metalava breccias and metatuffs, but also as disseminations forming sulphide-bearing rocks in all mafic units except of some massive flows.

The ore proper forms stockwork and network type breccias and fracture fillings which display folded and streaky structures. Pyrrhotite, followed by chalcopyrite, is by far the most abundant sulphide mineral at Haveri. Pyrite occurs in two generations and is seldom sufficiently abundant to be included in the main sulphides on the hand specimen level. Stigzelius (1944) considered the deposit epigenetic, but Mäkelä (1980) interpreted the sulphide breccias as syngenetic and regarded the disseminated sulphides and oxides in the mafic rocks as products of liquid immiscibility and therefore syngenetic with the silicate melt. Noting that the sulphides were enriched in ${ }^{34} \mathrm{~S}$ (range of $\delta^{34} \mathrm{~S}$ -0.5 to +8.7 per mil, average 6.3 per mil), Mäkelä (1980) concluded that the bulk of the sulphur originated through mixing of magmatic and sea-water sulphurs, and correlated the Haveri deposit with Cyprus-type sulphide ores.

When mining operations ceased in 1960, the total production of the Haveri Mine had amount- 
ed to $1.5 \mathrm{Mt}$ of ore averaging $2.8 \mathrm{~g} / \mathrm{t} \mathrm{Au}$ and $0.37 \% \mathrm{Cu}$ (Isokangas 1978). Currently the deposit is undergoing a new feasibility study by Baltic Minerals Finland Oy (cf. Eilu 1999).

\section{RESULTS}

Ten whole rock samples from the metabasalts of the Haveri Formation were analysed for their $\mathrm{Pb}$ and $\mathrm{Nd}$ isotopic compositions and their $\mathrm{U}, \mathrm{Pb}, \mathrm{Sm}$ and Nd concentrations. All samples are from drill core, from which material was selected on the basis of freshness and petrography to represent as wide a spectrum of the metabasalts as possible. In order to cover the ore genetic aspect, twelve chalcopyrite separates from the Haveri Formation from the vicinity of the Haveri Mine representing the stockwork breccia mineralisation were analysed for their lead isotopic composition.

The whole rock samples were dissolved in a $\mathrm{HF}_{-} \mathrm{HNO}_{3} \mathrm{mix}$ in teflon bombs sealed in steel jackets. The chalcopyrite samples were dissolved in $\mathrm{HCl}-\mathrm{HNO}_{3}$. The purification of lead and uranium were done using the methods described by Vaasjoki (1989), and the lead isotopic data were normalized to the accepted values of the NBS SRM981 common lead standard (cf. Gulson et al. 1984). To test the homogeneity of ore lead, three separate analyses were carried out on sample HVR9-2, which is a fine-grained sulphide concentrate, and two analyses were done on HVR10, which consists of rather coarse-grained chalcopyrite.

For Sm-Nd analyses the samples were dissolved in $\mathrm{HF}-\mathrm{HNO}_{3}$ using Savillex screw-cap teflon beakers following methods described by Huhma (1986). Measurements were made in a dynamic mode on a VG Sector 54 mass spectrometer using triple filaments. Although the average value for the La Jolla standard, ${ }^{143} \mathrm{Nd} /{ }^{144} \mathrm{Nd}=0.511840$ \pm 10 ( $1 \mathrm{SD}, \mathrm{N}=18$ ), seems reasonable, occasional biased values were recorded due to worn-out Faraday buckets. This problem clearly disappeared after bucket replacement.

The lead isotopic analyses from the whole rock samples form a linear array which yields an age estimate of $1954 \pm 140$ Ma with a mean square of weighted deviates (MSWD) of 3.6 (regression analysis using the ISOPLOT-program, Ludwig 1988). When the two most deviating samples (HVR2/102-103m; HVR2/211-212m) are excluded from the calculation, the result is $1990 \pm 62 \mathrm{Ma}$ with an MSWD of 0.7 . Exclusion of one more sample (HVR13/124.8m) gives an age estimate of $1942 \pm 88 \mathrm{Ma}$ with an MSWD of 0.3. It is obvious that these estimates cannot be treated as true ages, but they nevertheless are consistent with the Haveri Formation being emplaced at an early phase of the deposition of the Tampere Schist Belt 1.9-2.0 Ga ago.

From the ${ }^{207} \mathrm{~Pb} /{ }^{204} \mathrm{~Pb}$ vs. ${ }^{206} \mathrm{~Pb} /{ }^{204} \mathrm{~Pb}$ diagram (Fig. 4a) it is obvious that the whole rock array plots well below the average global lead evolution curve of Stacey and Kramers (1975), and passes close to the least radiogenic sulphide lead (HVR10b). The lead contents of the whole rock samples are higher than usual in mafic rocks. The uranium contents, on the other hand, are low at less than $1 \mathrm{ppm}$, which results in a relatively small range of the ${ }^{204} \mathrm{~Pb}$-related lead isotopic ratios. As is usual, the sample with the highest lead content is the least radiogenic one and samples containing less lead become progressively more radiogenic. From the ${ }^{208} \mathrm{~Pb} /{ }^{204} \mathrm{~Pb}$ vs. ${ }^{206} \mathrm{~Pb} /{ }^{204} \mathrm{~Pb}$ diagram (Fig. 4b) a Th/U ratio of 3.9 can be estimated.

In contrast to the bulk of the whole rock data, lead isotopic analyses from the chalcopyrites exhibit a scattering pattern. The two samples from which several dissolutions have been made (HVR9 and HVR10), exhibit definite inhomogeneity in their lead isotopic composition. Also, most analyses contain excess ${ }^{207} \mathrm{~Pb}$ when compared to the whole rock data (Fig. 4a), and the Th/U ratios for the chalcopyrites appear to be variable and much lower than that of their host rocks (Fig. 4b). An interesting feature is that two samples (HVR10b and HVR9-4) plot close to the line determined by the Svecokarelian orogenic leads (Vaasjoki 1981) while all others contain a larger proportion of ${ }^{206} \mathrm{~Pb}$.

The metabasalts analysed have fairly uniform $\mathrm{Sm} / \mathrm{Nd}$ ratios which suggest slight enrichment in LREE, compatible with the patterns shown by 
Table 1. U-Pb analyses from the Haveri metabasalts.

\begin{tabular}{llcccc}
\hline $\begin{array}{l}\text { Sample: } \\
\text { Drill hole/depth }\end{array}$ & \multicolumn{2}{c}{$\begin{array}{c}\text { Concentrations } \\
\mathrm{Pb} \text { (tot) }\end{array}$} & $\begin{array}{l}\text { Lead ratios } \\
206 / 204\end{array}$ & $207 / 204$ & $208 / 204$ \\
\hline HVR2/102.0-102.5 m & .39 & 8.87 & 15.687 & 15.170 & 35.501 \\
HVR2/104.0-104.5 m & .22 & 5.39 & 15.602 & 15.118 & 35.355 \\
HVR2/211.0-211.5 m & .19 & 3.41 & 16.077 & 15.203 & 36.136 \\
HVR3/ 69.0-69.5 m & .34 & 8.26 & 15.629 & 15.117 & 35.414 \\
HVR3/ 79.5-80.0 m & .43 & 8.74 & 15.816 & 15.140 & 35.552 \\
HVR5/131.2-131.7 m & .40 & 3.63 & 16.544 & 15.224 & 36.136 \\
HVR8/153.5-154.0 m & .20 & 4.70 & 15.744 & 15.134 & 35.353 \\
HVR10/ 53.0-53.5 m & .51 & 25.76 & 15.138 & 15.047 & 34.816 \\
HVR13/115.3-115.8 m & .81 & 4.33 & 19.270 & 15.548 & 39.496 \\
HVR13/124.8-125.3 m & .36 & 1.85 & 19.653 & 15.619 & 39.845 \\
\hline
\end{tabular}

Concentrations in ppm. Isotopic ratios normalized to NBS SRM981.

Table 2. Lead isotopic composition of sulphides from the Haveri area.

\begin{tabular}{lccc}
\hline $\begin{array}{l}\text { Sample: } \\
\text { Drill hole/depth }\end{array}$ & ${ }^{206} \mathrm{~Pb} /{ }^{204} \mathrm{~Pb}$ & ${ }^{207} \mathrm{~Pb} /{ }^{204} \mathrm{~Pb}$ & ${ }^{208} \mathrm{~Pb} / 204 \mathrm{~Pb}$ \\
\hline HVR3/52.30 m & 18.905 & 15.597 & 35.397 \\
HVR5/27.30 m & 15.108 & 15.066 & 34.714 \\
HVR8/183.30 m & 15.054 & 15.057 & 34.700 \\
HVR9-1/26.23 m & 15.704 & 15.169 & 34.995 \\
HVR9-2a/26.25 m & 16.562 & 15.314 & 35.227 \\
HVR9-2b/26.25 m & 16.076 & 15.196 & 34.738 \\
HVR9-2c/26.25 m & 16.472 & 15.240 & 34.917 \\
HVR9-3/26.27 m & 15.763 & 15.243 & 34.813 \\
HVR9-4/27.55 m & 15.908 & 15.391 & 35.305 \\
HVR10a/85.30 m & 14.948 & 15.056 & 34.666 \\
HVR10b/85.30 m & 14.696 & 14.993 & 34.451 \\
\hline
\end{tabular}

All data normalized to NBS SRM981.

Small letters in sample codes denote separate dissolutions from the same sample.
Kähkönen and Nironen (1994). The neodymium $\varepsilon$-values at $1900 \mathrm{Ma}$ range from -0.7 to +1.5 (Table 3 ), the mean value being $+0.5 \pm 0.6$ (if an age of $2000 \mathrm{Ma}$ is used the values are c. $0.4 \varepsilon$-unit higher). These values clearly deviate from a coeval depleted mantle source (DePaolo 1981) and suggest that the Haveri metabasalts originate from a source which has been enriched in LREE for a considerable amount of time.

\section{DISCUSSION}

\section{Origin of the metabasalts}

Geochemical studies (Mäkelä 1980, Kähkönen \& Nironen 1994) indicate that the mafic rocks of the

Table 3. Sm-Nd data on the Haveri metavolcanic rocks.

\begin{tabular}{|c|c|c|c|c|c|c|}
\hline $\begin{array}{l}\text { Sample: } \\
\text { Drill hole/depth }\end{array}$ & $\begin{array}{c}\mathrm{Sm} \\
(\mathrm{ppm})\end{array}$ & $\begin{array}{c}\mathrm{Nd} \\
(\mathrm{ppm})\end{array}$ & $\begin{array}{l}{ }^{147} \mathrm{Sm} / \\
{ }^{144} \mathrm{Nd}\end{array}$ & ${ }^{143} \mathrm{Nd} /{ }^{144} \mathrm{Nd} \pm 2 \sigma$ & $\mathrm{fi}_{\mathrm{Nd}}(1900)$ & $\begin{array}{c}\text { T-DM } \\
(\mathrm{Ma})\end{array}$ \\
\hline HVR-2/102.0-102.5 & 5.16 & 18.90 & 0.1652 & $0.512282 \pm 15$ & 0.7 & 2407 \\
\hline HVR-2/104.0-104.5 & 5.14 & 19.05 & 0.1630 & $0.512229 \pm 10$ & 0.2 & 2468 \\
\hline HVR-2/211.0-211.5 & 4.72 & 17.42 & 0.1639 & $0.512269 \pm 11$ & 0.7 & 2384 \\
\hline HVR-3/69.0-69.5 & 4.75 & 17.85 & 0.1608 & $0.512268 \pm 10$ & 1.5 & 2240 \\
\hline HVR-3/79.5-80.0 & 5.02 & 18.54 & 0.1638 & $0.512266 \pm 17$ & 0.7 & 2391 \\
\hline HVR-10/53.0-53.5 & 3.77 & 14.51 & 0.1569 & $0.512150 \pm 11$ & 0.1 & 2411 \\
\hline HVR-13/115.3-115.8 & 5.05 & 19.26 & 0.1584 & $0.512125 \pm 10$ & -0.7 & 2553 \\
\hline
\end{tabular}

Error in ${ }^{147} \mathrm{Sm} /{ }^{144} \mathrm{Nd}$ is $0.5 \% .{ }^{143} \mathrm{Nd} /{ }^{144} \mathrm{Nd}$ ratio is normalized to ${ }^{146} \mathrm{Nd} /{ }^{144} \mathrm{Nd}=0.7219$ and corrected after La Jolla ratio ${ }^{143} \mathrm{Nd} /{ }^{144} \mathrm{Nd}=0.51185$. The error in $\mathrm{fi}$ is 0.5 units.

T-DM is calculated according to DePaolo (1981). 
a.

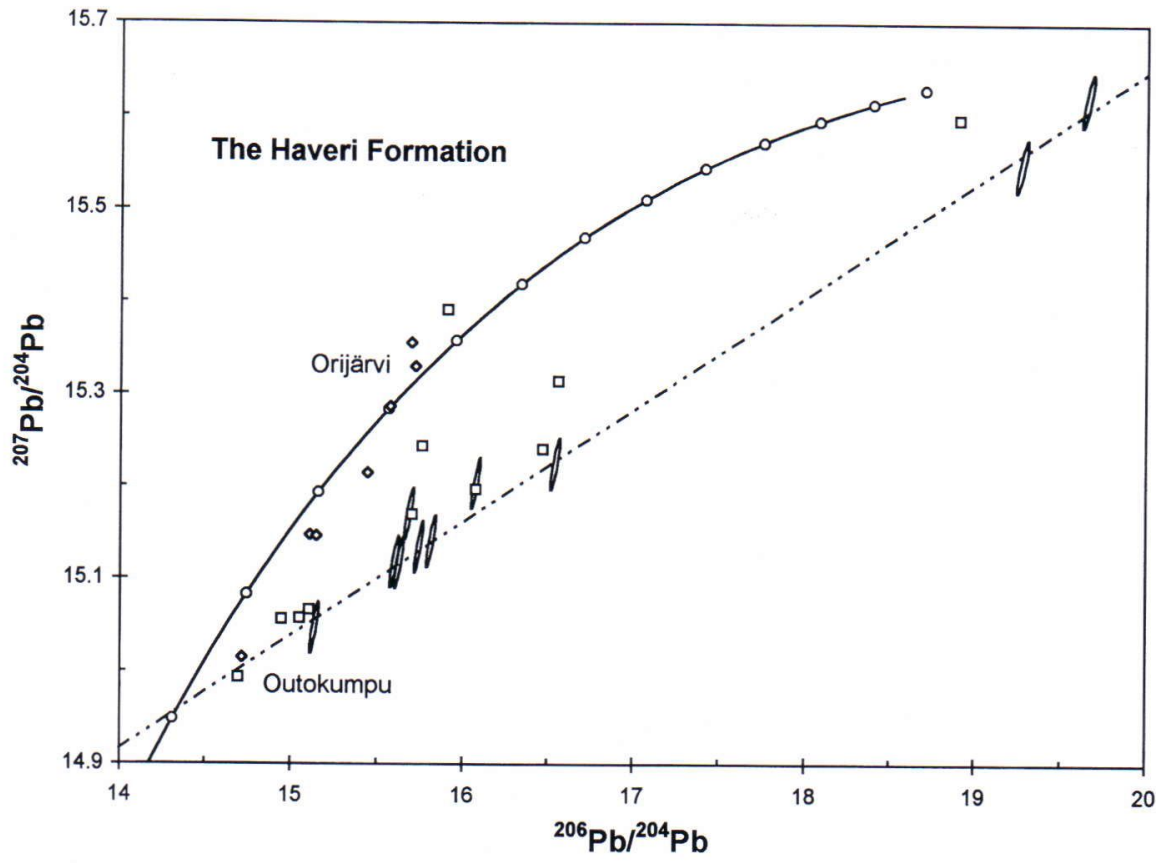

b.

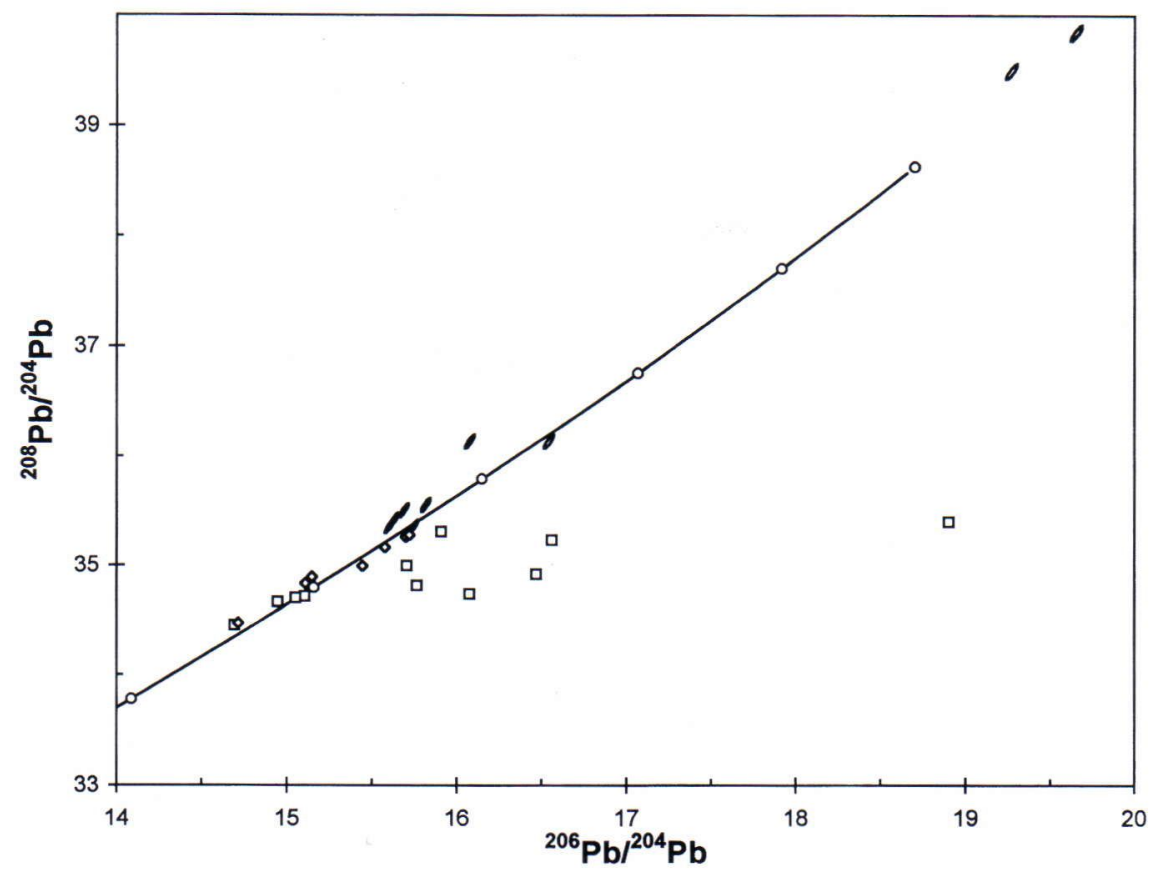

Fig. 4. Lead isotopic analyses of metabasalts (ellipses) and sulphides (squares) from the Haveri area. Data from Tables 1 and 2. Some Svecokarelian orogenic leads (diamonds) from Vaasjoki $(1981,1989)$ as well as the average global lead evolution curve of Stacey and Kramers (1975) are shown for reference. The size and shape of the ellipses reflect the analytical uncertainty. 
Haveri Formation differ substantially from other metavolcanic rocks within the Tampere Schist Belt. One of the most notable differences is the concentration of $\mathrm{TiO}_{2}$, which is significantly higher in the Haveri metabasalts (ca. 1.7 wt\%). According to Kähkönen and Nironen (1994), the Haveri metabasalts are mostly low-K/medium-K tholeiites tectonomagmatically similar to marginal basin basalts, whereas most metavolcanic rocks within the Tampere Schist Belt are calc-alkaline rocks with arc-type affinities.

The radiometric age estimate derived from the lead isotopic trend of the whole rock samples from the Haveri Formation is, in spite of its uncertainty, indicative of a relatively early origin during the evolution of the Tampere Schist Belt. This is in good agreement with field observations as the mafic rocks in the Haveri area seem to be on a lower stratigraphic level than the greywacke sediments (Kähkönen \& Nironen 1994), which in turn are thought to be low in the overall stratigraphic column of the Tampere Schist Belt.

The lead isotopic composition of the chalcopyrite separate HVR10 $\left({ }^{206} \mathrm{~Pb} /{ }^{204} \mathrm{~Pb}=14.70 ;{ }^{207} \mathrm{~Pb} /\right.$ ${ }^{204} \mathrm{~Pb}=14.99$ ) is the least radiogenic measured within the Svecofennian domain. This composition can well be close to the initial $\mathrm{Pb}$ isotopic composition of the whole rocks (Fig. 4), and suggests that the source has had a relatively low U/ $\mathrm{Pb}$ ratio for a considerable amount of time. This precludes the involvement of upper crustal material in the genesis of the Haveri metabasalts. According to the plumbotectonic model (Doe \& Zartman 1979) the source could be either an old lower crust or a mantle, but a contribution of lower crustal material is not compatible with the geochemical data (Kähkönen \& Nironen 1994, Lahtinen 1994).

The initial $\mathrm{Nd}$ isotopic composition for the $\mathrm{Ha}$ veri metabasalts differs clearly from a coeval depleted mantle (e.g. Huhma 1986, Huhma et al. 1990), and suggests an origin from a source which has been enriched in LREE for a considerable amount of time. The $\mathrm{Pb}$ and $\mathrm{Nd}$ isotopic and geochemical information thus suggest an enriched mantle source for the Haveri metabasalts (see also Lahtinen \& Huhma 1997).

\section{Ore genesis}

The combined lead isotopic and geologic data suggest that the metabasalts of the Haveri Formation were emplaced before the introduction of the syntectonic granitoids of the Svecofennian orogeny. As the least radiogenic chalcopyrite lead (HVR10b) plots on the extension of the linear fit to the whole rock data and five other sulphide analyses containing an excess of ${ }^{206} \mathrm{~Pb}$ also plot close to or on the metabasalt trend, it is feasible to suggest that at least part of the sulphide material and the basaltic melt had a common source. The fact that some of the chalcopyrite samples contain a similar amount of radiogenic ${ }^{206} \mathrm{~Pb}$ as the most radiogenic metabasalt samples can be interpreted as indicating that they remained quite unaffected by external processes since the Svecofennian orogeny.

The random scatter of sulphide lead isotopic composition on hand specimen scale implies a variation of the ${ }^{207} \mathrm{~Pb} /{ }^{204} \mathrm{~Pb}$ ratio induced close to their time of formation. Variations of the magnitude observed cannot arise from radioactive decay during a short period but must be the result of mixing of isotopically deviating leads derived from geologically different sources. The excess ${ }^{207} \mathrm{~Pb}$ in many of the chalcopyrite samples indicates an episode of significant upper crustal contamination, with circulating fluids as a transporting medium. It is evident that one source for the sulphides was the host basaltic sequence. The other end member is more obscure, but may have been similar to the sample with the apparently highest component of initial ${ }^{207} \mathrm{~Pb}$ (HVR9-4). Its isotopic composition is similar to that of the ores in the Svecofennian supracrustal rocks (e.g. Orijärvi, Vaasjoki 1981).

The large scatter observed in lead isotopic composition implies that the primitive lead and high ${ }^{207} \mathrm{~Pb}$ were not homogenized during metamorphism. This suggests that the fluid activity which introduced the addition of high ${ }^{207} \mathrm{~Pb}$ material either took place after the peak of metamorphism or the metamorphism did not homogenize the $\mathrm{Pb}$ isotopic composition on a hand specimen scale. It is interesting to note in this context, that sulphide 
remobilization occurred during the $\mathrm{D}_{2}$ phase of deformation (Nironen 1994), which probably is coeval with the granitoid intrusions (Kähkönen \& Nironen 1994, Fig. 5). It is likely that some ${ }^{207} \mathrm{~Pb}-$ rich material was introduced also into the whole rock samples. This would make the age connotations of the whole rock $\mathrm{Pb}-\mathrm{Pb}$ regressions questionable.

Studies from the East Pacific Rise (Brevart et al. 1981, Vidal \& Clauer 1981) demonstrate that sulphides formed in the vicinity of hydrothermal vents are isotopically homogeneous and plot below the average global lead evolution curves. Data demonstrate that neither seawater nor hemipelagic sediments contribute significant amounts of continental lead to sulphides formed in an oceanic environment (Vidal \& Clauer 1981). A similar result has been obtained for the Besshi deposits in Japan (Sato \& Sasaki 1980) and the Permian Mt. Chalmers deposit in Australia (Gulson \& Vaasjoki 1987) which are associated with rocks of presumed mantle derivation. Also some island arc deposits (Kuroko; Fehn et al. 1983) contain leads which plot below the average global lead evolution curves. However, not all island arc related base metal ores behave in this manner. Thus the Palaeozoic volcanogenic deposits in eastern Australia conform to the average lead evolution models (Gulson \& Vaasjoki 1987).

The results from Haveri thus suggest that no significantly older crustal material was available when the basalts and syngenetic primary sulphides formed. Later fluids carrying Archaean upper crustal lead derived from the local metasedimentary rocks contributed to the sulphide mineralisation. It remains open to which mineralising phase the formation of the Au ore was related.

\section{Crustal development}

The initial lead isotopic composition inferred from the whole rocks and measured on the Haveri chalcopyrites is identical within experimental error to the Outokumpu galenas (cf. Vaasjoki 1981). This provokes to study the correlation between the Haveri formation and the 1.95-1.96 Ga Outokumpu and Jormua ophiolites near the Archaean craton margin in eastern Finland. The Sm-Nd data on Outokumpu are probably too sparse for comparison. Recent geochemical and $\mathrm{Sm}-\mathrm{Nd}$ isotopic data on the Jormua ophiolite suggest that the main basalt suite has E-MORB-like characteristics with $\varepsilon_{\mathrm{Nd}}(1950)$ of ca. +1.9 , whereas few "early dykes" represent OIB-like alkaline suite with $\varepsilon_{\mathrm{Nd}}(1950)$ of ca. 0 (Peltonen et al. 1996). The tectonic setting of the Haveri Formation is quite different from that of Outokumpu and Jormua, as the oldest rocks dated in the Tampere Schist Belt are just slightly over $1.9 \mathrm{Ga}$. However, as discussed by Lahtinen and Huhma (1997), the overall geochemical and isotopic data of the Tampere Schist Belt and adjacent areas are best explained by assuming the occurrence of evolved thick crust and associated lithosperic mantle already at $1.91 \mathrm{Ga}$. Lahtinen (1994) suggests that the magmatism at Haveri was related to a pre- $1.91 \mathrm{Ga}$ rifting stage, but the available isotopic data provide neither strict age constraints nor correlation with ophiolites.

\section{CONCLUSIONS}

On the basis of the results of our analytical work and the preceeding discussion we conclude that:

1) The metabasalts of the Haveri Formation were derived from a mantle segment which had been enriched in LREE for a considerable time period.

2) Lead isotopic data indicate that the main sulphide mineralisation is genetically related to the metabasalts. The initial lead isotopic composition is the least radiogenic measured in the Svecofennian domain.

3) The second mineralising phase involved old upper crustal lead derived from the local sedimentary rocks.

4) The preservation of the Haveri Formation and the overall geochemical and isotopic data on the area suggest that continental crust was forming in the Tampere Schist Belt area already before the culmination of the Svecofennian orogeny, but probably not earlier than 1.95 $\mathrm{Ga}$ ago. 
ACKNOWLEDGEMENTS. We wish to thank Dr. Kaarlo Mäkelä (Outokumpu Oy) for providing the sample material. Dr. Irmeli Mänttäri, Tuula Hokkanen, Marita Niemelä, Matti Karhunen and Matti Sakko assisted in various ways during the analytical work. Critical comments by Drs. Raimo Lahtinen (Geological Survey of Finland) and Torbjörn Skiöld (Naturhistoriska Riksmuseet, Sweden) are greatly appreciated.

\section{REFERENCES}

Brevart, O., Dupré, B. \& Allègre, C.J. 1981. Metallogenesis at spreading centers: lead isotopic systematics of sulphides, manganese-rich crusts, basalts and sediments from the Cyamex and Alvin areas (East Pacific Rise). Economic Geology 77, 564-575.

Campbell, D.S. 1980. Structural and metamorphic development of migmatites in the Svecokarelides, near Tampere, Finland. Transactions of the Royal Society of Edinburgh: Earth Sciences 76,185-200.

Claesson, S., Huhma, H., Kinny, P.D. \& Williams, I.S. 1993. Svecofennian detrital zircon ages - implications for the Precambrian evolution of the Baltic Shield. Precambrian Research 64, 109-130.

DePaolo, D.J. 1981. Neodymium isotopes in the Colorado Front Range and crust-mantle evolution in the Proterozoic. Nature 291, 684-687.

Doe, B.R. \& Zartman, R.E. 1979. Plumbotectonics I. The Phanerozoic. In: Barnes, H.L. (ed.) Geochemistry of Hydrothermal Ore Deposits. New York: John Wiley \& Sons, 22-70.

Eilu, P. 1999. FINGOLD - A public database on gold deposits in Finland. Geological Survey of Finland, Report of Investigation 146. 224 p.

Fehn, U., Doe, B.R. \& Delevaux, M.H. 1983. The distribution of lead isotopes and origin of Kuroko ore deposits in the Hokuroku district, Japan. Economic Geology Monograph 5, 488-506.

Gaál, G., Front, K. \& Aro, K. 1981. Geochemical exploration of a Precambrian batholith, source of a $\mathrm{Cu}-\mathrm{W}$ mineralization of the tourmaline breccia type in southern Finland. Journal of Geochemical Exploration 15, 683698.

Gulson, B.L. \& Vaasjoki, M. 1987. Lead isotope data from the Thalanga, Dry River and Mt Chalmers base metal deposits and their bearing on exploration and ore genesis in eastern Australia. Australian Journal of Earth Sciences 34, 159-173.

Gulson, B.L, Gorsch, M.J., Cameron, M., Vaasjoki, M., Mizon, K.J., Porritt, P.M., Carr, G.R., Kamper, C., Dean, J.A. \& Calvez, J.-Y. 1984. Lead isotope ratio measurements using the Isomass $54 \mathrm{E}$ in fully automatic mode. International Journal of Mass-spectrometry and Ion
Processes 59, 125-142.

Huhma, H. 1986. Sm-Nd, U-Pb and $\mathrm{Pb}-\mathrm{Pb}$ isotopic evidence for the origin of the Early Proterozoic Svecokarelian crust in Finland. Geological Survey of Finland, Bulletin 337.48 p.

Huhma, H. 1987. Provenance of early Proterozoic and Archaean metasediments in Finland: a Sm-Nd isotopic study. Precambrian Research 35, 127-144.

Huhma, H., Cliff, R.A., Perttunen, V. \& Sakko, M. 1990. $\mathrm{Sm}-\mathrm{Nd}$ and $\mathrm{Pb}$ isotopic study of mafic rocks associated with early Proterozoic continental rifting; the Peräpohja schist belt in northern Finland. Contributions to Mineralogy and Petrology 104, 369-379.

Huhma, H., Claesson, S., Kinny, P.D. \& Williams, I.S. 1991. The growth of Early Proterozoic crust: new evidence from Svecofennian detrital zircons. Terra Nova 3, 175-179.

Isokangas, P. 1978. Finland. In: Mineral Deposits of Europe, Vol.1: Northwest Europe. London: Institution of Mining and Metallurgy and Mineralogical Society, 3992.

Kähkönen, Y. 1989. Geochemistry and petrology of the metavolcanic rocks of the early Proterozoic Tampere Schist Belt, southern Finland. Geological Survey of Finland, Bulletin 345. 107 p.

Kähkönen, Y. \& Leveinen, J. 1994. Geochemistry of metasedimentary rocks of the Palaeoproterozoic Tampere Schist Belt, southern Finland. Geological Survey of Finland, Special Paper 19, 117-140.

Kähkönen, Y. \& Nironen, M. 1994. Supracrustal rocks around the Palaeoproterozoic Haveri $\mathrm{Au}-\mathrm{Cu}$ deposit, southern Finland: evolution from a spreading center to a volcanic arc environment. Geological Survey of Finland, Special Paper 19, 141-160.

Kähkönen, Y., Huhma, H. \& Aro, K. 1989. U/Pb zircon and ${ }^{87} \mathrm{Sr} /{ }^{86} \mathrm{Sr}$ whole rock determinations of igneous rocks of the Proterozoic Tampere Schist Belt. Precambrian Research 45, 27-43.

Kouvo, O. \& Tilton, G.R. 1966. Mineral ages from the Finnish Precambrian. Journal of Geology 74, 421-442.

Lahtinen, R. 1994. Crustal evolution of the Svecofennian and Karelian domains during 2.1-1.79 Ga, with special emphasis on the geochemistry and origin of 1.93-1.91 $\mathrm{Ga}$ gneissic tonalites and associated supracrustal rocks in the Rautalampi area, central Finland. Geological Survey of Finland, Bulletin 378. 128 p.

Lahtinen, R. \& Huhma, H. 1997. Isotopic and geochemical constraints on the evolution of the 1.93-1.79 Ga Svecofennian crust and mantle in Finland. Precambrian Research 82, 13-34.

Ludwig, K.R. 1988. ISOPLOT - A plotting and regression program for radiogenic isotope data for IBM-PC compatible computers. United States Geological Survey, Open File Report 88-557. 32 p.

Mäkelä, K. 1980. Geochemistry and origin of Haveri and Kiipu, Proterozoic stratabound volcanogenic gold-copper and zinc mineralizations from southwestern Finland. Geological Survey of Finland, Bulletin 310. 79 p. 
Neuvonen, K.J. \& Matisto, A. 1948. Some observations on the tectonics in the Tampere schist area. Bulletin de la Commission géologique de Finlande 142, 79-86.

Nironen, M. 1989. Emplacement and structural setting of granitoids in the early Proterozoic Tampere and Savo Schist Belts, Finland - Implications for contrasting crustal evolution. Geological Survey of Finland, Bulletin $346.83 \mathrm{p}$.

Nironen, M. 1994. Structural control and (re)mobilization of the extinct Haveri $\mathrm{Au}-\mathrm{Cu}$ deposit, southern Finland. Bulletin of the Geological Society of Finland 66, 3944.

Patchett, J. \& Kouvo, O. 1986. Origin of continental crust of 1.9-1.7 Ga age: $\mathrm{Nd}$ isotopes and $\mathrm{U}-\mathrm{Pb}$ zircon ages in the Svecokarelian terrain of South Finland. Contributions to Mineralogy and Petrology 92, 1-12.

Peltonen, P., Kontinen, A. \& Huhma, H. 1996. Petrology and geochemistry of metabasalts from the 1.95 Ga Jormua Ophiolite, northeastern Finland. Journal of Petrology $37,1359-1383$.

Sato, K. \& Sasaki, A. 1980. Lead isotopic feature of the Besshi-type deposits and its bearing on the ore lead evolution. Geochemical Journal 14, 303-315.

Sederholm, J.J. 1897. Über eine archäische Sedimentformation im südwestlichen Finland und ihre Bedeutung für die Erklärung der Entstehungsweise des Grundgebirges. Bulletin de la Commission géologique de Finlande 6 . $254 \mathrm{p}$.

Seitsaari, J. 1951. The schist belt northeast of Tampere in Finland. Bulletin de la Commission géologique de Finlande $153.120 \mathrm{p}$.
Simonen, A. 1952. Kallioperäkartan selitys - Explanation to the map of rocks, Lehti - Sheet - 2124, ViljakkalaTeisko. Suomen geologinen kartta - Geological map of Finland. Geologinen tutkimuslaitos. 74 p.

Simonen, A. 1953. Stratigraphy and sedimentation of the Svecofennidic early Archaean supracrustal rocks in southwestern Finland. Bulletin de la Commission géologique de Finlande 160. 64 p.

Simonen, A. 1980a. Pre-Quaternary rocks of Finland 1:1 000 000. Geological Survey of Finland.

Simonen, A. 1980b. The Precambrian in Finland. Geological Survey of Finland, Bulletin 304. 58 p.

Simonen, A. \& Kouvo, O. 1951. Archaean varved schists north of Tampere in Finland. Bulletin de la Commission géologique de Finlande 154, 93-114.

Stacey, J.S. \& Kramers, J.D. 1975. Approximation of terrestrial lead isotope evolution by a two-stage model. Earth and Planetary Science Letters 26, 207-221.

Stigzelius, H. 1944. Über die Erzgeologie des ViljakkalaGebietes im südwestlichen Finnland. Bulletin de la Commission géologique de Finlande 134. 91 p.

Vaasjoki, M. 1981. The lead isotopic composition of some Finnish galenas. Geological Survey of Finland, Bulletin 316.30 p.

Vaasjoki, M. 1989. Pb and S isotopic studies on the Rauhala $\mathrm{Zn}-\mathrm{Cu}-\mathrm{Pb}$ sulphide deposit and its environment. Geological Survey of Finland, Special Paper 11, 59-65.

Vidal, Ph. \& Clauer, N. 1981. Pb and Sr isotopic systematics of some basalts and sulphides from the East $\mathrm{Pa}$ cific Rise at $21^{\circ} \mathrm{N}$ (project RITA). Earth and Planetary Science Letters 55, 237-246. 